\title{
Sensory and nutritional evaluation of unleavened flat bread prepared by multigrain flour mixture
}

\author{
Shikha Singh*, AnishaVerma and Neeru Bala \\ Department of Foods and Nutrition, SHIATS, Allahabad-211007(U.P.), INDIA \\ * Corresponding author. E-mail: singh.shikha489@gmail.com \\ Received: December 27, 2015; Revised received: April 06, 2016; Accepted: July 05, 2016
}

\begin{abstract}
The present study was undertaken to develop the value added food product using multigrain flour mixture and to assess its sensory and nutritional composition of unleavened flat bread (Chapatti). It was standardized as Control $\left(\mathrm{T}_{0}\right)$. Along with control; three variations of Chapatti were prepared by replacing wheat flour with different ratio of multigrain flour mixture which referred as $T_{1}, T_{2}, T 3$ and $T_{4}$ respectively. They were tested for different attributes (Taste and Flavour, Colour and Appearance, Body and Texture and Overall Acceptability). A food composition table given by Gopalan, et.al, 2007 was used to determine the nutritional composition of Chapatti. Appropriate statistical technique was opted for the analysis. The result revealed that the $T_{1}(8.05 \pm 0.00)$ was found most acceptable with regards to its sensory attributes followed by $T_{0}(7.70 \pm 0.42), T_{2}(7.55 \pm 0.08), T_{3}(7.22 \pm 0.98)$ and $T_{4}(6.64 \pm 0.46)$ respectively. Energy (ranging from 388-436 Kcal), Protein (ranging from 22-28 g), fat (ranging from 13-21 g), calcium (ranging from145-192 mg), phosphorus (ranging from 466-501 mg), fiber (ranging from 3-4g) and iron (ranging from 6-7 mg) were increased in treatments as compared to control except carbohydrate. Thus, it can be concluded that value added product has good organoleptic and nutritional quality.
\end{abstract}

Keywords: Chapatti Multigrain flour, Nutritional, Organoleptic quality, Unleavened flat bread

\section{INTRODUCTION}

Chapatti, an unleavened flat bread of Indian origin is popular in majority of the households. Basically, chapatti is prepared using whole wheat flour. Wheat is the second most produced food among the cereal crops (USDA, 2003). Cereal grains provide an incredible 68 per cent of the world food supply. It is commonly known that the main nutritional drawback of cereal is their low protein contents and limited biological quality of their protein (highly deficient in lysine and tryptophan) (Waliszewski et al., 2000), when compared with animal protein. It is recognized as a major staple food and the cheapest source of protein and calories. Legumes proteins are major components of the diet of food-producing animals and are increasingly important in human nutrition. Soybean [Glycine max.] is the most important legume in relation to total world grain production and the most frequently used because of its high protein contents and relatively low prices. It is rich in lysine and are, therefore, a good complement to wheat protein that is deficient in lysine contents.it contains good amount of isoflavones, genistein and daidzein, which have recently been implicated as contributors to its hypocholesterolaemic effect (Ridges et. al., 2001).

Barley (Hordeum vulgare L.), a member of the grass family, is a major cereal grain. It was one of the first cultivated grains and is now grown widely. According to research conducted by Shimizu et.al., (2008) , $\beta$ - glucan present in barley reduces the serum cholesterol. Flax (Linum usitatissimum) is an annual plant belonging to the family of Linaceae. It has been identified as a functional food, whose benefits to health are generally attributed to high concentrations of linolenic acids (omega-3) and lignins, as well as significant quantities of dietary fiber. Sesame seed is a rich source of protein. The flour that remains after oil extraction contains protein between 35 to 50 percent. It has good effective carbohydrates, and contains water-soluble antioxidants. It is also a good source of manganese, copper, calcium, iron, phosphorus, vitamin $\mathrm{B}_{1}$, zinc and dietary fiber. Curry leaves (Murraya koenigii Linn) commonly known as 'Meethi neem', belongs to the family Rutaceae. Curry leaves used traditionally as antiemetic, antidiarrhoeal and blood purifier. The whole plant is considered to be a tonic and stomachic. It was found to be effective as antioxidant, antidiabetic, antibacterial, antihypertensive, cytotoxic and also in the treatment of bronchial respiratory difficulties (Saini and Reddy, 2013).

The present study was designed to utilize soy flour, sesame seed, whole wheat flour, flaxseed, barley and carrot to develop a low fat and nutrient rich product which act as an important functional food in pharmaceutical industries as well as to evaluate the feasibility of substituting wheat chapattis with other cheap and healthy plant based food materials to enhance its organoleptic and nutritional qualities. 


\section{MATERIALS AND METHODS}

Experimental Sites: The present investigation was carried out in the Nutrition Research Laboratory of the Department of Foods and Nutrition, Ethelind School of Home Science, Sam Higginbottom Institute of Agriculture, Technology and Sciences (Deemed to be University), (Formerly Allahabad Agricultural Institute) Allahabad, U.P.

Procurement of Raw Materials: Basic ingredients for preparation were purchased from the local market of Allahabad.

Development of Food Product: Nutritious healthy Chapatti was developed by using wheat flour, Soy flour, Flaxseed, Barley flour, gingelly seed and curry leaves powder. The basic recipes were standardized and served as control $\left(\mathrm{T}_{0}\right)$. Along with the control $\mathrm{T}_{0}$, on the basis of acceptability wheat flour was replaced by other flour mixture and was referred as $T_{1}, T_{2}, T_{3}$, $\mathrm{T}_{4}$ respectively.

Treatments and Replications of Developed Food Product: $\mathrm{T}_{0}: 100$ percent Wheat flour

$\mathrm{T}_{1}$ : 40 percent Wheat flour +30 percent Soybean flour + 5 percent Flaxseed flour +10 percent Barley flour +10 percent Gingelly seed powder +5 percent Curry leaves $\mathrm{T}_{2}$ : 30 percent Wheat flour +35 percent Soybean flour + 10 percent Flaxseed flour +10 percent Barley flour+ 10 percent Gingelly seed powder +5 percent Curry leaves $\mathrm{T}_{3}$ : 20 percent Wheat flour +40 percent Soybean flour + 15 percent Flaxseed flour+ 10 percent Barley flour+ 10 percent Gingelly seed powder +5 percent Curry leaves $\mathrm{T}_{4}$ : 10 percent Wheat flour +45 percent Soybean flour + 20 percent Flaxseed flour+ 10 percent Barley flour+ 10 percent Gingelly seed powder +5 percent Curry leaves Organoleptic analysis of developed food product: Prepared product was served to panel of five experienced members. Panel members were rated the product with the help of nine points hedonic scale based score card (Srilakshmi, 2007).

Determination of Nutritive Value of the Developed Food Product: The nutritional composition of product was done by using food composition table given by

Gopalan et al, (2007).

Statistical Analysis : The data obtained from sensory evaluation were statistically analysed by using analysis of variance technique (two way classification), critical difference test and t test (Banerjee, 2013).

\section{RESULTS AND DISCUSSION}

The average sensory scores of various sensory attributes viz; colour \& appearance, taste and flavour, body and texture and overall acceptability is presented in Fig. 1. Average sensory score of Chapatti in relation to Colour and Appearance had the highest in $\mathrm{T}_{0}$ $(8.5 \pm 0.27)$, followed by $\mathrm{T}_{1}(8.0 \pm 0.23), \mathrm{T}_{2}(7.5 \pm 0.81)$, $\mathrm{T}_{3}(7.33 \pm 0.27), \mathrm{T}_{4}(6.33 \pm 0.27)$ respectively. The calculated value of $F$ (15.6) was higher than the table value of F (3.84) at 5\% level of significance. This shows that there is significant difference between the colour and appearance of control and treatments indicating that the addition of different proportions of flaxseed and soybean affect the Colour and Appearance of the prepared product. The colour becomes darker and acceptability level decreases as the amount increases after a certain limit. The difference in the mean value of $\mathrm{T}_{1}$, $\mathrm{T}_{0}(0.5) ; \mathrm{T}_{2}, \mathrm{~T}_{0}(1.0) ; \mathrm{T}_{3}, \mathrm{~T}_{0}(1.17) ; \mathrm{T}_{4}, \mathrm{~T}_{0}(2.17) ; \mathrm{T}_{2}, \mathrm{~T}_{1}$ (0.5); $\mathrm{T}_{3}, \mathrm{~T}_{1}(0.67) ; \mathrm{T}_{4}, \mathrm{~T}_{1}(1.67) ; \mathrm{T}_{4}, \mathrm{~T}_{2}(1.17)$ and $\mathrm{T}_{4}$, $\mathrm{T}_{3}$ (1.0) was greater than $\mathrm{CD}(0.322)$ therefore the difference was significant. The difference in the mean value of $\mathrm{T}_{2}, \mathrm{~T}_{3}(0.17)$ was less than $\mathrm{CD},(0.336)$ there-

Table. 1. Average nutrients content in control and different treatments of Chapatti per 100gm.

\begin{tabular}{llllll}
\hline Nutrients & $\begin{array}{l}\text { Con- } \\
\text { trol }\end{array}$ & \multicolumn{2}{l}{ Treatments } \\
\cline { 2 - 6 } & $\mathbf{T}_{\mathbf{0}}$ & $\mathbf{T}_{\mathbf{1}}$ & $\mathbf{T}_{\mathbf{2}}$ & $\mathbf{T}_{\mathbf{3}}$ & $\mathbf{T}_{\mathbf{4}}$ \\
\hline Moisture (g) & 1 & 11 & 10 & 9 & 8 \\
Energy(kcal) & 341 & 388 & 402 & 436 & 430 \\
Carbohydrate (g) & 69 & 46 & 40 & 37 & 32 \\
Protein (g) & 12 & 22 & 24 & 26 & 28 \\
Fat(g) & 2 & 13 & 15 & 18 & 21 \\
Fiber (g) & 2 & 3 & 3 & 3 & 4 \\
Calcium (mg) & 48 & 145 & 161 & 177 & 192 \\
Phosphorus (mg) & 355 & 449 & 466 & 484 & 501 \\
Iron (mg) & 5 & 6 & 6 & 7 & 7 \\
\hline
\end{tabular}

Table 2. Comparison of nutritional composition of control and best treatment $\left(\mathrm{T}_{1}\right)$ of Chapatti.

\begin{tabular}{|c|c|c|c|c|c|c|}
\hline Nutrients & $\mathbf{T}_{\mathbf{0}}$ & $\mathbf{T}_{1}$ & $\begin{array}{l}\text { Difference } \\
\left(t_{0}-t_{1}=D\right)\end{array}$ & $\begin{array}{l}\mathbf{T} \\
\text { (Calculated) }\end{array}$ & $\begin{array}{l}\text { T (Tabulated) } \\
t_{0.05,2}\end{array}$ & Result \\
\hline Moisture (g) & 12.2 & 12.605 & -0.405 & 2.13 & 4.30 & NS \\
\hline Energy (Kcal) & 341 & 387.8 & -46.8 & 19.05 & 4.30 & S \\
\hline Carbohydrate (g) & 69.4 & 45.87 & 23.53 & 64.64 & 4.30 & S \\
\hline $\operatorname{Protein}(\mathrm{g})$ & 12.1 & 22.1 & -10 & 16.44 & 4.30 & S \\
\hline Fat $(g)$ & 1.7 & 12.895 & -11.195 & 28.81 & 4.30 & S \\
\hline Calcium(mg) & 48 & 145.25 & -97.25 & 78.57 & 4.30 & S \\
\hline Phosphorus (mg) & 355 & 448.85 & -93.85 & 28.76 & 4.30 & S \\
\hline $\operatorname{Iron}(\mathrm{mg})$ & 4.9 & 6.40 & -1.5 & 2.26 & 4.30 & NS \\
\hline
\end{tabular}

S-Significant, NS- Non Significant 


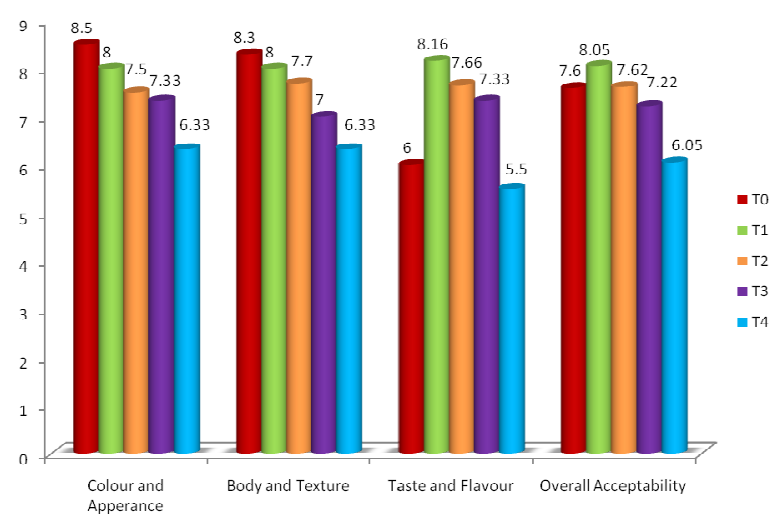

Fig 1. Average Sensory Score of Different sensory attributes of Chapatti

fore the difference was non-significant. The mean score for Body and Texture was highest in $\mathrm{T}_{0}$ $(8.3 \pm 0.99)$, followed by $\mathrm{T}_{1}(8.0 \pm 0.81), \mathrm{T}_{2}(7.70 \pm 0.23)$, $\mathrm{T}_{3}(7.0 \pm 0.00), \mathrm{T}_{4}(6.33 \pm 0.27)$ respectively. The calculated value of $\mathrm{F}$ (14.11) was higher than the table value $\mathrm{F}(3.84)$ at $5 \%$ probability level. This shows that there is significant difference between the Body and texture of control and treatments. The addition of different proportions of flaxseed and soybean affect the Body and Texture of the prepared products by diminishing cohesiveness and resilience, increasing the hardening thereby decreasing the acceptability level. The difference in the mean values of $\mathrm{T}_{1}, \mathrm{~T}_{0}(0.3) ; \mathrm{T}_{2}, \mathrm{~T}_{0}(0.6) ; \mathrm{T}_{3}$, $\mathrm{T}_{0}(1.3) ; \mathrm{T}_{4}, \mathrm{~T}_{0}(1.97) ; \mathrm{T}_{2}, \mathrm{~T}_{1}(0.3) ; \mathrm{T}_{3}, \mathrm{~T}_{1}(1.0) ; \mathrm{T}_{4}, \mathrm{~T}_{1}$ (1.67); $\mathrm{T}_{3}, \mathrm{~T}_{2}(0.7) ; \mathrm{T}_{4}, \mathrm{~T}_{2}(1.37)$; and $\mathrm{T}_{4}, \mathrm{~T}_{3}(0.67)$ was greater than $C D(0.20)$, therefore the difference was significant. Similarly Sheikh et.al., (2015) reported that the $10 \%$ of soybean and $10 \%$ of flaxseed (multi-mix gluten free flours) incorporation with in Chapattis obtained maximum score for various sensory attributes. The mean score for Taste and Flavour was highest in $\mathrm{T}_{1}(8.16 \pm 0.40)$, followed $\mathrm{T}_{2}(7.66 \pm 0.81), \mathrm{T}_{3}$ $(7.33 \pm 0.27), \mathrm{T}_{0},(6.0 \pm 0.00), \mathrm{T}_{4}(5.5 \pm 0.00)$ respectively. The calculated value of $F(18.32)$ was higher than the table value $\mathrm{F}(3.84)$ at $5 \%$ level of significance. Addition of different proportions of flaxseed and soybean increased the Taste and Flavour of the prepared products but as flaxseed and soybean proportions is increased Taste and Flavour decreased and hence the treatments have significant influence against the CD value $(0.65)$. The mean score for Overall acceptability was highest in $T_{1}(8.05 \pm 0.00)$, followed $T_{2}$ (7.62 \pm 0.08$), \quad \mathrm{T}_{0} \quad(7.60 \pm 0.42), \quad \mathrm{T}_{3} \quad(7.22 \pm 0.98) \quad \mathrm{T}_{4}$ $(6.05 \pm 0.46)$ respectively. Bhise and Kaur, (2013) studied the sensory properties of unleavened flat bread. Incorporation of $10 \%$ of texturized defatted sunflower, soybean and flaxseed was most acceptable. Khan, et.al., (2009) founded that organoleptic characteristic of chapattis was altered by blending wheat flour with soy flour. There was a significant $(p>0.05)$ difference between treatments. The average nutrient content in treatments and control of Chapatti / 100 gm was shown in Table 1. It was clearly shown in the table that Energy(ranged from 388-436 Kcal), protein (ranged from 22-28 g), fat (ranged from 13-21 g), fiber (ranged from3-4g), Calcium (ranged from145-192mg), phosphorus (ranged from 466-501mg) and Iron (ranged from 6-7 mg) more in treatments as compared to control $\mathrm{T}_{0}$. Carbohydrate content was found to be highest in $\mathrm{T}_{0}(69 \mathrm{~g})$ followed by $\mathrm{T}_{1}(46 \mathrm{~g}) \mathrm{T}_{2}(40 \mathrm{~g}), \mathrm{T}_{3}(37), \mathrm{T}_{4}$ (32 g) respectively. Therefore it can be concluded that with increase in amount of flaxseed and soybean flour in Chapatti the percentage of nutrients are increased. According to Rathi and Mogra (2013) partial replacement of wheat flour with up to 30 percent of flaxseed flour had obtained good acceptance as well as considered as excellent source of linolenic acid and dietary fiber.

Table 2 shows the comparison of nutritional composition of control and best acceptable treatment $\left(\mathrm{T}_{1}\right)$ of chapatti. On applying the $t$ test it was clearly shown in the table that there is a significant difference at 5\% level of significance between the nutrients of control and treatment.

\section{Conclusion}

The formulations made with up to 30 per cent soybean and 5 per cent flaxseed as partial replacement of wheat flour had good acceptance, and the product presented good acceptable scores. Energy, protein, fiber, calcium and iron are higher in multigrain unleavened bread in comparison to control. The study showed that with the increase in amount of multigrain flour mix in chapatti, the percentage of nutrients is increased significantly. Thus, the multigrain composite flour can be included in daily diet through its incorporation into wheat flour used for production of chapattis.

\section{REFERENCES}

Banerjee, P. (2013). Introduction to Biostatistics, $4^{\text {th }}$ Ed. S.Chand Company (P) Ltd., New Delhi, 51-85.

Bhise, S. and Kaur A., (2013). Development of Functional Chapatti from Texturized Deoiled Cake of Sunflower, Soybean and Flaxseed. Int. Journal of Engineering Research and Applications, Vol. 3, Issue 5, pp.1581-1587

Gopalan, C., Balasubramamian, C. S. and Sastri Rama, V. B. (2007). Nutritive Value of India Foods. IV ${ }^{\text {th }}$ edition, printed by National Institute of Nutrition (NIN), ICAR .48-61.

Khan, M.I., Anjum, F.M., Zahoor, T., Sarwar M.,and Wahab, S. (2009). Nutritional characterization of the wheat-soy unleavened flat bread by rat bioassay. Sarhad J. Agric. Vol.25, No.1.

Rathi, P. and Mogra, R. (2013). Development and sensory evaluation of superior products with flaxseed. Int $J$ of Food and Nutritional Sci .2(1):13-15.

Ridges, L., Sunderland, R., Moerman, K., Meyer, B., Astheimer, L. and Howel, P. (2001). Cholesterol lowering benefits of soy and linseed enriched foods. Asia Pacific J Clin Nutr. 10(3): 204-211 
Shikha Singh et al. / J. Appl. \& Nat. Sci. 8 (3): 1168-1171 (2016)

Saini, S. C. and Reddy, G.B.S.(2013). Murraya koenigii. J of Pharmacy and Biological Sci. 7(6): 15-18

Sheikh, S., Gupta, A., Vetolu and Sahai, R. (2014). Sensory Evaluation and Nutritional composition of utilization of Multi-Flour mix in the preparation of Gluten free Snacks. The Allahabad Farmer 69(2):103-108.

Shimizu, C., Kihara, M., Aoe, S., Araki, S., Ito, K., Hayashi, K., Watari, J., Sakata, Y. and Ikegami, S. (2008). Effect of high beta-glucan barley on serum cholesterol concentrations and visceral fat area in Japanese men--a ran- domized, double-blinded, placebo-controlled trial. Plant Foods Hum Nutr, 63(1):21-5.

Srilakshmi, B. (2007). Food science, $4^{\text {th }}$ Ed. New age international (P) Ltd. New Delhi. 170-174.

USDA. (2003). Annual World Production Summary, Grains. Washington, DC. USA

Waliszewski, N.K., Estrada, Y., and Parido, V. (2000). Lysine and tryptophan fortification of nixtamalized corn flour. Int. J. Food Sci. Tech. 35: 523-7. 